\title{
EVOLUTION OF THE ILLECILLEWAET GLACIER, GLACIER NATIONAL PARK, B.C., USING HISTORICAL DATA, AERIAL PHOTOGRAPHY AND SATELLITE IMAGE ANALYSIS
}

by

André Champoux and C.S.L. Ommanney

(National Hydrology Research Institute, Environment Canada, Ottawa, Ontario K1A OE7, Canada)

\section{ABSTRACT}

The Illecillewaet Glacier (British Columbia) has been surveyed in a variety of ways since the end of the 19th century. A summary of the different information - archive photographs, field surveys, photo-interpretation, and remote sensing - reveals that between 1887 and 1962, the glacier had retreated more than one kilometre. However, since 1972 , it has advanced about $100 \mathrm{~m}$. The techniques used and the results are discussed.

\section{INTRODUCTION}

The history of the Illecillewaet Glacier, located in south-east British Columbia $\left(51^{\circ} 14.1^{\prime} \mathrm{N}, 117^{\circ} 26.5^{\prime} \mathrm{W}\right)$, occupies a special place in the history of glaciological investigations in Canada. Although, by European standards, the quality and quantity of information is not great (cf., e.g., Swiss National Tourist Office 1981), by Canadian standards, it is one of the few glaciers for which we have a long and reasonably consistent record. The construction of the transcontinental railway line through Rogers Pass, in 1885, first gave scientists and others an opportunity to study it. The following year, the Canadian Pacific Railway Company (CPR) built an hotel for its customers in the heart of their "Canadian Pacific Rockies". Glacier House was then some 45 minutes walking distance from the glacier snout. This proximity, coupled with the hotel's facilities, attracted a number of investigators, of whom the most persistent were members of the Vaux family, of Philadelphia. In 1887, they began a series of surveys of the variation and movement of the glacier (Cavell 1983). Subsequently, other investigators joined them here and on other glaciers of the region (Asulkan, Yoho, Victoria, etc.).

\section{PRE-WAR SURVEYS}

The most popular technique, in the early years, consisted of annual photographs of the glacier from fixed points. These enabled members of the Vaux family, amongst others, to monitor the retreat of the Illecillewaet Glacier intermittently from 1887 to 1912. In addition, the rate of movement of ice in the ablation area was determined by triangulation, from fixed points, of a number of steel plaques, placed on the ice. Others were encouraged to supplement the record by photographing the glacier from the fixed points. Figure 1 shows the front of the Illecillewaet Glacier from rock "W"; (a) in 1899 by William S. Vaux (1909); (b) in 1931 by A.O. Wheeler (1932); and (c), in 1946 by C.E. Webb (unpublished report). The distance the glacier retreated between 1887 and 1946 was about $1300 \mathrm{~m}$.

Observations were made more or less continuously until 1912. Afterwards, they were sporadic, due to the closing of Glacier House, the Great War, and the Depression.

\section{WATER SURVEY OF CANADA (WSC) SURVEYS}

In 1945, the Dominion Water and Power Bureau, forerunner of the WSC, decided to include the Illecillewaet Glacier in its annual snout and surface movement surveys.

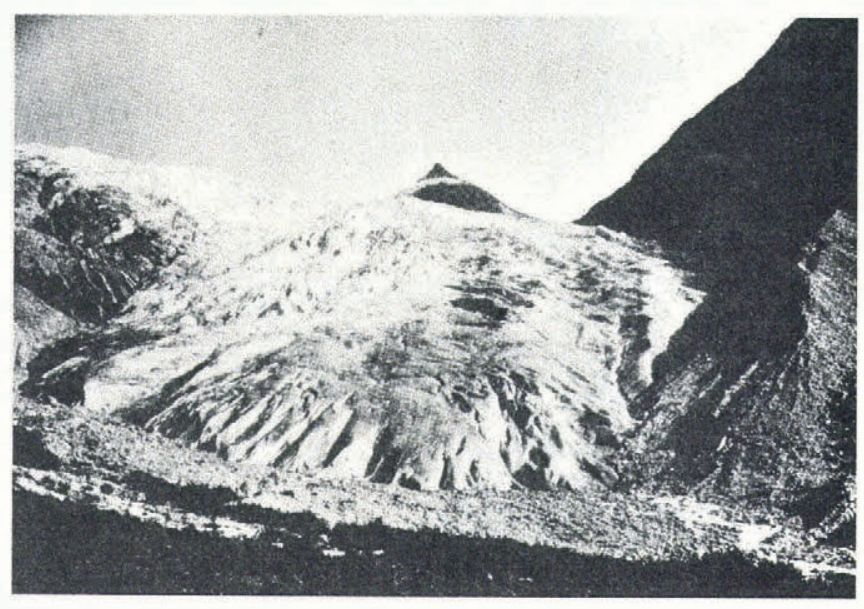

Fig.1(a) Illecillewaet Glacier 1899 (Vaux 1909).

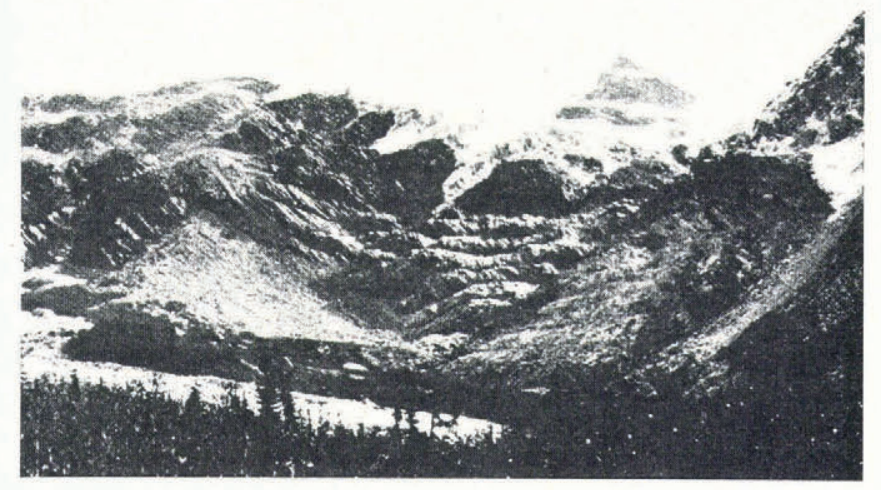

Fig.1(b) Illecillewaet Glacier 1931 (Wheeler 1932).

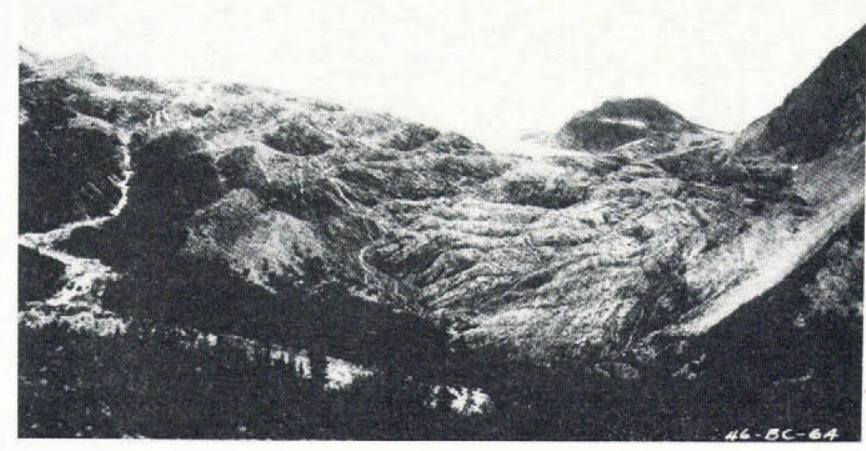

Fig.1(c) Illecillewaet Glacier 1946 (C.E. Webb unpublished report). 
Two different measurement techniques were used. In one, a base line was established below the snout, approximately parallel to it. The area between was measured and converted into a single, mean, linear, retreat value. The second was similar, but the base line was established across the glacier above the snout. Re-surveys were made every year at

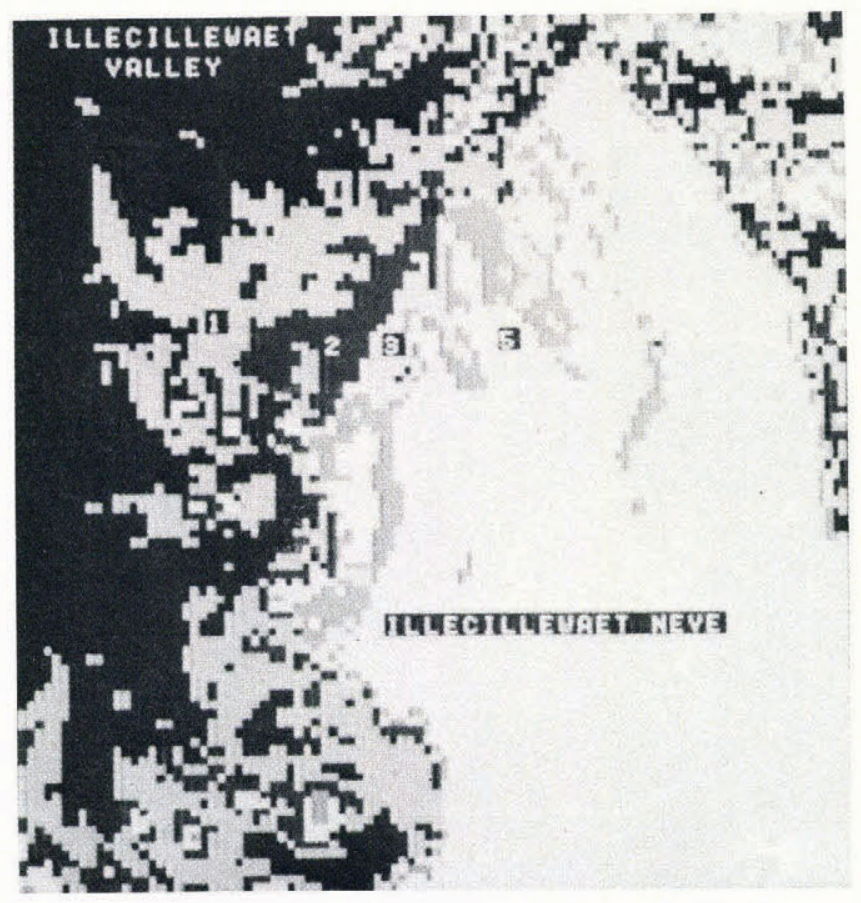

Fig.2. Unsupervised classified LANDSAT image of Illecillewaet Glacier area. Scale 1:50 000, 12 August 1981. approximately the same date until 1950 and then every two years to 1960. From 1960 until 1971, no measurements were made.

\section{PARKS CANADA SURVEYS}

Illecillewaet Glacier is in Glacier National Park. In 1972, the Park Naturalist Service implemented an annual snout survey, based on field measurement from fixed points, which continues to the present. The first observations showed that the glacier had, indeed, stopped its retreat phase sometime between 1963 and 1971. Subsequently, they measured a total re-advance of $91.75 \mathrm{~m}$ from 1972 to 1984 . Table 1 summarizes the various observations from 1887 to 1984 and shows a net retreat of $1433 \mathrm{~m}$, when the various figures are averaged together.

\section{GLACIER INVENTORY SURVEY}

A tripartite glacier inventory of the Park, based on air photo interpretation, includes additional information on the Illecillewaet Glacier, its extent and characteristics, at the end of the Little Ice Age (approximately 1850), in the early 1950's and in 1978 (Champoux and Ommanney 1986), which is summarized in Table 2. Up to 1951-52, the glacier lost about $28 \%$ of its area and has recovered about $1 \%$ since then. These figures apply to the whole glacier complex and not just the tongue area. The mean depth does not vary, because the glacier, at its maximum and minimum sizes, still falls within the same glacier-inventory, depth-estimate category.

Careful examination of enlargements of a number of recent aerial photographs has confirmed a thickening of the glacier tongue since 1972. This and the $50^{\circ}$ tongue slope, observed in the field, imply that the advance is likely to continue for a number of years.

\section{REMOTE SENSING}

The use of LANDSAT MSS images for this study was subject to two main problems - the poor spatial resolution (59 $\times 79 \mathrm{~m}$ ) and cloud cover; shadows were removed in the

TABLE I: GLACIER VARIATIONS 1887 TO 1984 (METRES)

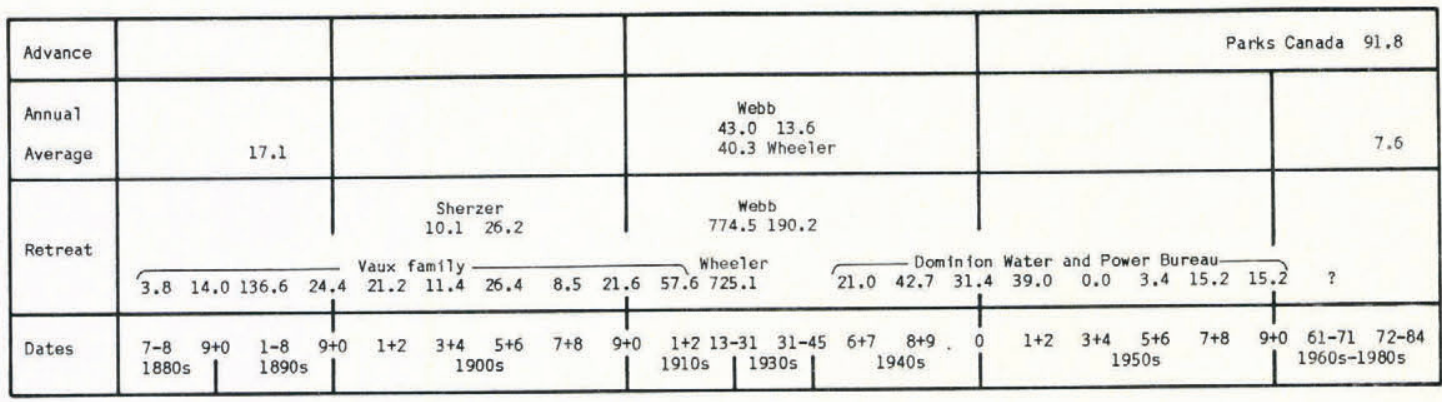

TABLE II: ILLECILLEWAET GLACIER INVENTORY DATA

\begin{tabular}{|c|c|c|c|c|c|c|c|c|c|c|c|c|c|}
\hline Dates & \multicolumn{7}{|c|}{ Elevations (metres above sea level) } & \multicolumn{4}{|c|}{ Areas $\left(\mathrm{km}^{2}\right)$} & Depth m & Volume $\mathrm{km}^{3}$ \\
\hline 1978 & 2300 & 2800 & 2540 & 2248 & 1980 & 1980 & 2526 & 6.78 & 6.78 & 0.77 & 88 & 100 & 0.677 \\
\hline $1951-52$ & 2500 & 2800 & 2580 & 2380 & 2000 & 2000 & 2521 & 6.70 & 6.70 & 3.06 & 54 & 100 & 0.670 \\
\hline $\begin{array}{l}\text { Little } \\
\text { Ice Age }\end{array}$ & - & 2800 & - & - & - & 1460 & 2451 & 9.27 & 9.27 & 2.78 & - & 100 & 0.927 \\
\hline 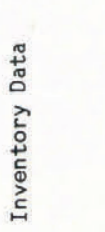 & 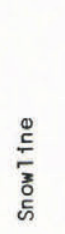 & 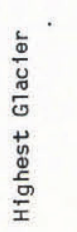 & 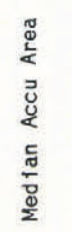 & 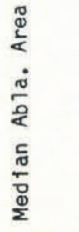 & 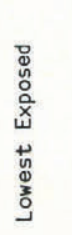 & $\begin{array}{l}\frac{L}{\Phi} \\
\frac{\pi}{U} \\
\\
E \\
\frac{E}{E} \\
\frac{E}{\Sigma}\end{array}$ & $\begin{array}{l}\frac{1}{\Phi} \\
\frac{0}{0} \\
0 \\
\frac{0}{0} \\
\frac{\Phi}{2}\end{array}$ & $\begin{array}{l}\frac{1}{0} \\
\frac{\pi}{0} \\
0 \\
\overline{0} \\
\stackrel{0}{0}\end{array}$ & 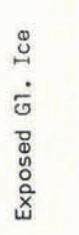 & $\begin{array}{l}\frac{0}{0} \\
\frac{2}{2} \\
\frac{5}{0} \\
\frac{0}{0} \\
\frac{0}{8}\end{array}$ & 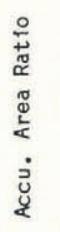 & 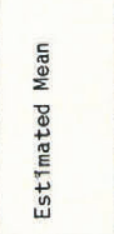 & 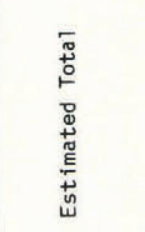 \\
\hline
\end{tabular}




\section{REFERENCES}

Cavel E 1983 Legacy in ice - the Vaux family and the Canadian alps. Banff, Alberta, Peter and Catherine Whyte Foundation

Champoux A C, Ommanney C S L 1986 Photointerpretation, digital mapping, and the evolution of glaciers in Glacier National Park, B.C. Annals of Glaciology 8: 27-30

Ommanney C S L, Ross E Unpublished Bibliography: Glacier National Park, British Columbia. Ottawa, Ontario, Environment Canada. National Hydrology Research Institute (Glacier National Park Glacier Inventory Report 1)

Vaux W S 1909 Modern glaciers. Canadian Alpine Journal 2(1): $56-78$

Webb C E Unpublished Report on investigations of glaciers in British Columbia. Vancouver, British Columbia, Department of Mines and Resources. Mines, Surveys and Engineering Branch. Dominion Water and Power Bureau (Internal Report 2207)

Wheeler A O 1932 Glacial change in the Canadian Cordillera - the 1931 expedition. Canadian Alpine Journal 20, 1931: $120-137$ 